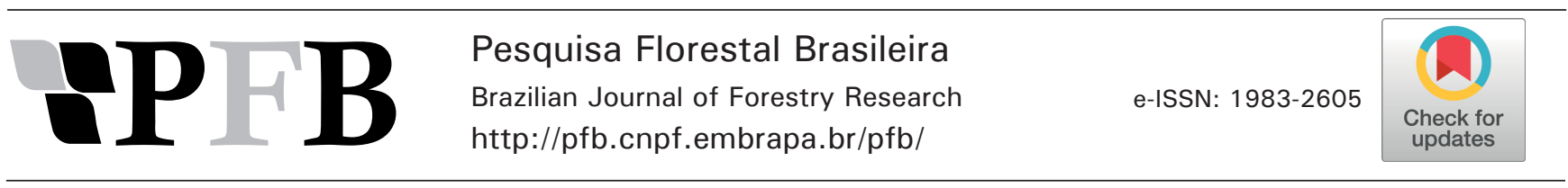

\title{
Weight is a key factor in the physiological quality of Parapiptadenia rigida seeds
}

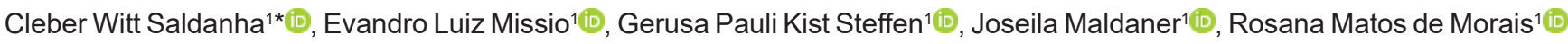 \\ ${ }^{1}$ Secretaria da Agricultura, Pecuária e Irrigação, Centro de Pesquisa em Florestas, BR 287, Acesso VRS 830, Km 4,5, Boca do Monte, CEP 97170-000, Santa \\ Maria, RS, Brazil
}

"Corresponding author:
clebersaldanha@yahoo.com.br

Index terms:

Accelerated aging

Germination

Seed size

Termos para indexação:

Envelhecimento acelerado

Germinação

Tamanho de semente

Received in 21/09/2017

Accepted in 21/05/2018

Published in 11/07/2018

doi: 10.4336/2018.pfb.38e201701501

\begin{abstract}
This study aimed to assess the physiological quality of Parapiptadenia rigida (Benth.) Brenan seed weight classes subjected to accelerated aging under laboratory and greenhouse conditions. A lot of $P$. rigida seeds was split in three seed weight classes (thousand seed weight): TSW1 (original lot; control, 19.23 g), TSW2 (25.45 g) and TSW3 (13.58 g), which were subjected to three accelerated aging times $(0,24$ and $48 \mathrm{~h})$. First count, weak and strong normal seedlings, percentage of accumulated germination, percentage of death seed, electrical conductivity, fresh and dry weight and shoot length were assessed in laboratory. Seedling emergence, emergence velocity and emergence velocity index were assessed in greenhouse. $P$. rigida seeds showing higher weight displayed higher percentage of germination and average vigor characteristics. Seeds with higher weight indicated high tolerance to accelerated aging conditions and produced more vigorous plants. Therefore, we suggest that seed lots of $P$. rigida should be composed considering TSW classes.
\end{abstract}

\section{Massa é fator determinante na qualidade fisiológica de sementes de Parapiptadenia rigida}

Resumo - O presente estudo teve por objetivo avaliar em laboratório e em casa de vegetação a qualidade fisiológica de classes de massa de sementes de Parapiptadenia rigida (Benth.) Brenan, submetidas a condições de envelhecimento acelerado. Um lote de sementes de $P$. rigida foi separado em três grupos de massa de sementes (peso de mil sementes): PMS1 (lote original; controle, 19,23 g), PMS2 (25,45 g) e PMS3 (13,58 g); e submetido a três tempos de envelhecimento acelerado (0, 24 e 48 h). Em laboratório, foram avaliadas: primeira contagem, plântulas normais fracas e fortes, porcentagem de germinação acumulada, porcentagem de sementes mortas, condutividade elétrica, massas fresca e seca e comprimento da parte aérea das plântulas. Em casa de vegetação, foram avaliadas a emergência de plântulas, a velocidade de emergência e o índice de velocidade de emergência. Sementes de $P$. rigida com maior massa apresentaram maiores valores de porcentagem de germinação e características de vigor médias. Sementes com maior massa apresentaram indicativos de alta tolerância a condições de envelhecimento acelerado e possibilitaram a obtenção de plântulas mais vigorosas. Portanto, sugere-se que lotes de semente de $P$. rigida sejam constituídos por sementes classificadas pelo PMS. 


\section{Introduction}

Seed is a key element in plant production and has a deep influence in the success or failure of artificial or natural regeneration (Yang \& Wen, 2017). Approximately $70 \%$ of man-described plant species are seed-propagated (Marcos Filho, 2005). When scale multiplying is required for a given species, knowledge on seed physiology is critical. Among several characteristics, seed weight should be observed for propagation purposes (Baskin \& Baskin, 2014; Li \& Li, 2016).

Seed deterioration is the main problem in the production systems and physical as well as physiological conditions factors play a major role in its vigour (FinchSavage \& Bassel, 2016). Seed mass is a feature of great importance, linked to the recruitment via germination and establishment of seedlings (Genna \& Pérez, 2016). It is controlled predominantly by genetic information from maternal and zygotic tissues, though seed growth is also influenced by environmental cues ( $\mathrm{Li} \& \mathrm{Li}, 2016$ ).

Seed size is an important indicator of physical quality, directly related to germination, emergence and vegetative growth of plants of seminal origin (Ambika et al., 2014; Ghaffaripour et al., 2017; Yang \& Wen, 2017). In general, seeds displaying larger size or density are potentially more vigorous because they usually have more reserves and they present well-formed embryos (Carvalho \& Nakagawa, 2012; Suárez-Vidal et al., 2017), resulting in faster germination and proper seedling establishment. There are evidences that seed size selection of forest species can favor seedling production under nursery conditions, resulting in greater seedlings uniformity (Alves et al., 2005).

Variation in seed size produces seedlings with distinct growth potential. Extensive natural variation within species is observed for this trait (Gnan et al., 2014). Studies conducted with Gmelina arborea (Owoh et al., 2011), Tecoma stans (Socolowski et al., 2011b), Pterocarpus marsupium (Mishra et al., 2014), Sapindus mukorossi (Attri et al., 2015) and Tamarindus indica (Ghaffaripour et al., 2017) showed a direct relationship between seed weight or size and seedling vigor. However this should not be considered as a rule, as germination and seedlings growth of Tectona grandis (Khera et al., 2004) and Schizolobium parahyba (Freire et al., 2015) were not affected by seed size.

The study of the germinate behavior of forest species has been of great importance in the scientific environment, aiming to obtain information that expresses the physiological quality of seeds for conservation and propagation (Mondo et al., 2008).

Angico-vermelho (Parapiptadenia rigida (Benth.) Brenan) is a widely distributed tree species in the Atlantic Forest in Brazil, Paraguai, Uruguai and Argentina, and it is often indicated for riparian forest reforestation programs (Silva et al., 2010). Furthermore, this species is recommended in mixed reforestation, degraded and permanent preservation areas. It grows on both wet and dry soils, being more abundant in well-drained soils, occurring naturally in open and less dense forests as well as in secondary associations (Lorenzi, 1992; Carvalho, 2002). Traditionally, this species has been seedpropagated, requiring seed-technology-related studies to enable the establishment of sustainable plantings through seedlings with high morphophysiological quality.

There are no reports in the literature of the effect of $P$. rigida seed weight on germination and vigor or on the behavior of seeds under stress-simulated conditions through accelerated aging. Understanding species germination in response to seed weight can help in the definition of strategies of seedling production in nursery and of restoration programs. Therefore, this study aimed to assess the relationship between seed weight and physiological quality of $P$. rigida seeds in accelerated aging conditions.

\section{Material and methods}

Parapiptadenia rigida fruits were collected from four matrices in June 2014, in Santa Maria, Rio Grande

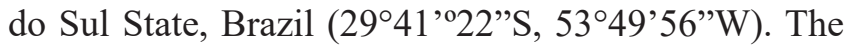
seeds were extracted and dried, composing one lot that was stored in a cool chamber (relative humidity of $45 \%$ to $60 \%$; temperature of $8{ }^{\circ} \mathrm{C}$ ). Physical analysis and germination test were carried out, showing 94\% germination, $99 \%$ purity, $14.9 \%$ moisture content and $19.23 \mathrm{~g}$ of thousand seeds weight (TSW).

The seed lot was manually split into three size categories and were characterized in analytical balance by mass (Brasil, 2009): original lot (TSW1 = $19.23 \mathrm{~g}$ ), seeds with higher weight (TSW2 $=25.45 \mathrm{~g}$ ), seeds with low weight $(\mathrm{TSW} 3=13.58 \mathrm{~g})$, which were subjected to three accelerated aging times.

The experiment was carried out in a completely randomized design in a factorial arrangement $(3 \times 3)$, consisting of the combination of three seed weight classes (TSW1, TSW2 and TSW3) and three accelerated aging times $(0,24$ and $48 \mathrm{~h})$, totaling nine treatments. 
The three seed classes (TSW1, TSW2 and TSW3) were subjected to accelerated aging in a moisture chamber at $41^{\circ} \mathrm{C}$ for 24 and $48 \mathrm{~h}$, following methodology adapted from McDonald Junior \& Phaneendranath (1978). Two hundred seeds from each treatment were stored in plastic boxes $(11.0 \mathrm{~cm} \times 11.0 \mathrm{~cm} \times 3.5 \mathrm{~cm})$ in a moisture chamber. Seeds were distributed on an aluminum screen fixed in each box and $40 \mathrm{~mL}$ of distilled water was added; then, the boxes were placed in a B.O.D. chamber (411D, Nova Ética).

\section{Laboratory assessments}

Assessment was carried out in a Mangelsdorf germination chamber (Biomatic ${ }^{\circledR}$ ), kept in room with temperature control. We evaluated four replications of 50 seeds for each treatment at $25{ }^{\circ} \mathrm{C}$, using the paper towel roll (PR) moistened with distilled water in a 2:1 ratio relative to their weight as a substrate. Counting was performed at 7 and 14 days (Brasil, 2013). Seeds were considered germinated when the radicle was at least $2 \mathrm{~mm}$ in length. Results were expressed as total percentage of seedling emergence.

The number of germinated seeds was monitored daily for 7 days after incubation. Germination velocity index (GVI) was calculated as shown by Maguire (1962).

First germination score was carried out during the first assessment of cumulative germination. In such test, normal-germinated-seedlings were scored and removed, assuming that they were more vigorous by germinating faster (Brasil, 2013). After first count, at seven days, 25 seedlings were randomly taken and measurement of total length (in $\mathrm{cm}$ ) for each replication was carried out using millimeter paper (adapted from Krzyzanowski et al., 1999).

Determinations of fresh and dry weight were carried out for all 25 seedlings of each replication that were used for shoot and radicle measurements, besides evaluation of normal strong and normal weak seedlings. They were weighed immediately in a scale with an accuracy of $0.001 \mathrm{~g}$. For dry mass determination, the material was placed in kraft paper bags and taken to a drying oven with mechanical air circulation at $65^{\circ} \mathrm{C}$ until constant weight.

Seedlings vigor classification was adapted from Krzyzanowski et al. (1999), and it was conducted concurrently with the germination test and the seedlings length measurements. Seedlings considered normal (Brasil, 2009) were assessed and classified visually regarding their vigor. Minimum standards of seedlings total length were established so those were considered normal strong seedlings. Normal strong seedlings were those that showed at least seven-centimeter-growth. Seedlings that did not reach such values were recorded as normal weak seedlings.

For electrical conductivity (EC) determination, 50 seeds per replication were used for each treatment, with four replications. Seeds of each replication were weighed before being subjected to accelerated aging in a moisture chamber in glass vials filled with $75 \mathrm{~mL}$ of deionized water for imbibition for $24 \mathrm{~h}$ at $25 \pm 2{ }^{\circ} \mathrm{C}$ (Vieira \& Krzyzanowski, 1999; Piña-Rodrigues et al., 2004). Afterwards, EC was determined in a conductivity meter (Tec-4MP, Tecnal).

\section{Seedling emergence in greenhouse}

The greenhouse experiment was performed with the same treatments as described before and conducted in gerbox containing vermiculite substrate (medium granulometry) with four replications of 50 seeds for each treatment. Substrate moisture was kept with daily moderated irrigations with deionized water. Periodic rotations of the experimental units were performed. Daily number of seedlings that emerged were recorded up to a constant number was obtained. Seven days after sowing, when there was no new seedling emergence, the test was ended (Brasil, 2009).

The number of emerged seedlings was calculated based on daily record up to 10 days after sowing. After ending the readings, emergence velocity index (EVI) was calculated by equation 1 (Maguire, 1962). Seedlings were considered emerged when presenting cotyledons completely above of the substrate level.

$$
\mathrm{EVI}=\mathrm{E} 1 / \mathrm{N} 1+\mathrm{E} 2 / \mathrm{N} 2+\ldots \mathrm{En} / \mathrm{Nn}
$$

In which: EVI = emergence velocity index; E1, E2, ... En $=$ number of normal seedlings computed at the first, second and last count; $\mathrm{N} 1, \mathrm{~N} 2, \ldots \mathrm{Nn}=$ number of days from sowing to first, second and last count.

Emergence velocity was calculated as shown by Edmond \& Drapala (1958), based on the same data from daily records of number of emerged seedlings used to obtain EVI (Equation 2).

$$
\mathrm{EV}=[(\mathrm{N} 1 \mathrm{G} 1)+(\mathrm{N} 2 \mathrm{G} 2)+\ldots+(\mathrm{NnGn})] /(\mathrm{G} 1+\mathrm{G} 2+\ldots+\mathrm{GN})
$$

In which: $\mathrm{EV}=$ emergence velocity (days); $\mathrm{G}=$ number of emerged seedlings in each count; $\mathrm{N}=$ number of days from sowing to each count. 
It was carried out during the first cumulative emergence assessment. In this test, seedlings that were considered normal were counted and withdrawn, also assuming that they were more vigorous by emerging faster (Brasil, 2009).

Cumulative emergence was performed at 7 and 14 days after sowing (Brasil, 2013). Results were expressed as percentage of emerged seedlings.

\section{Data analysis}

The variables were subjected to Shapiro Wilk's normality test, analysis of variance and Tukey's test ( $p$ $<0.05$ ) for mean comparisons, using Sisvar 5.6 software (Ferreira, 2011).

\section{Results}

There was a significant difference $(\mathrm{p}<0.05)$ of Parapiptadenia rigida seeds germination at the first count (seven days) in response to the thousand seed weight (TSW) classes (Table 1). Seeds with higher weight (TSW2) presented higher percentage of germination $(74.0 \%)$ at the first count, differing from the control treatment, that also differed from seeds with lower TSW (47.8\%).

In general, mean values of strong normal seedlings, fresh weight, dry weight and shoot length were higher in $P$. rigida seeds with higher weight. Seeds with lower TSW presented the highest average of weak seedlings (Table 1). Therefore, $P$. rigida seeds with high weight germinated in faster when compared to seedlots with lower TSW.

Table 1. Characteristics of seedling vigor of Parapiptadenia rigida from three groups with different thousand seed weight (TSW) at 14 days after incubation.

\begin{tabular}{|c|c|c|c|c|c|c|}
\hline TSW & $\begin{array}{c}\text { Germination* } \\
(\%)\end{array}$ & $\begin{array}{c}\text { Weak } \\
\text { normal } \\
(\%)\end{array}$ & $\begin{array}{c}\text { Strong } \\
\text { normal } \\
(\%)\end{array}$ & $\begin{array}{c}\text { Fresh } \\
\text { weight }^{-1} \\
\left(\text { g plant }^{-1}\right)\end{array}$ & $\begin{array}{c}\text { Dry } \\
\text { weight }^{-1} \text {. } \\
\left(\text { g plant }^{-1}\right)\end{array}$ & $\begin{array}{c}\text { Shoot } \\
\text { length } \\
\text { (cm) }\end{array}$ \\
\hline Class 1 & $60.66 b^{* *}$ & $23.64 \mathrm{~b}$ & $83.18 \mathrm{a}$ & $0.105 \mathrm{~b}$ & $0.012 \mathrm{~b}$ & $4.34 \mathrm{a}$ \\
\hline Class 2 & $74.00 \mathrm{a}$ & $20.18 b$ & $87.66 \mathrm{a}$ & $0.122 \mathrm{a}$ & $0.014 \mathrm{a}$ & $4.58 \mathrm{a}$ \\
\hline Class 3 & $47.83 \mathrm{c}$ & $38.04 \mathrm{a}$ & $61.85 \mathrm{~b}$ & $0.070 \mathrm{c}$ & $0.007 \mathrm{c}$ & $3.31 \mathrm{~b}$ \\
\hline $\mathrm{CV}(\%)$ & 12.39 & 20.61 & 9.79 & 4.80 & 6.24 & 9.29 \\
\hline
\end{tabular}

"First germination count was at seven days after incubation; TSW: Class $1=19.23 \mathrm{~g}$ (control); Class 2=25.45 g (TSW2); Class 3=13.58 g (TSW3). **Means followed by the same letter in column are not significantly different based on Tukey's test at $5 \%$ of error probability. $\mathrm{CV}=$ coefficient of variation.

TSW influenced the cumulative germination of $P$. rigida seeds after subjected to varying times of accelerated aging (Table 2). Percentages of germination and cumulative dead seeds (14 days) differed in response to the TSW and accelerated aging times interaction. However, only for seeds with TSW1 (original lot), it was observed a significant difference among the means of germination in response to aging time. Seeds with higher TSW presented high percentages of cumulative germination at different aging times (80.5 and 76.5\%) relative to the other TSW classes. Small seeds (class 3) presented the lowest percentages of germination under $48 \mathrm{~h}$ of accelerated aging.

Table 2. Percentages of cumulative germination and dead seeds of Parapiptadenia rigida from three different classes of thousand seed weight (TSW) submitted to three accelerated aging times.

\begin{tabular}{|c|c|c|c|}
\hline \multirow{2}{*}{ Time (h) } & \multicolumn{3}{|c|}{ TSW } \\
\hline & Class 1 & Class 2 & Class 3 \\
\hline & \multicolumn{3}{|c|}{ Germination (\%) } \\
\hline 0 & $75.5 \mathrm{Aa}$ & $76.5 \mathrm{Aa}$ & $47.5 \mathrm{Ba}$ \\
\hline 24 & $59 \mathrm{Bb}$ & $80.5 \mathrm{Aa}$ & $53.5 \mathrm{Ba}$ \\
\hline 48 & $57 \mathrm{Bb}$ & $76.50 \mathrm{Aa}$ & $46 \mathrm{Ba}$ \\
\hline \multirow[t]{2}{*}{ CV (\%) } & & 9.98 & \\
\hline & \multicolumn{3}{|c|}{ Dead seeds (\%) } \\
\hline 0 & $24.50 \mathrm{Bb}$ & $23.50 \mathrm{Ba}$ & $51.50 \mathrm{Aa}$ \\
\hline 24 & $41.00 \mathrm{Aa}$ & $19.50 \mathrm{Ba}$ & $46.50 \mathrm{Aa}$ \\
\hline 48 & $43.00 \mathrm{Aa}$ & $23.50 \mathrm{Ba}$ & $54.00 \mathrm{Aa}$ \\
\hline CV (\%) & \multicolumn{3}{|c|}{17.49} \\
\hline
\end{tabular}

TSW: Class $1=19.23 \mathrm{~g}$ (control); Class $2=25.45 \mathrm{~g}$ (TSW2); Class $3=13.58 \mathrm{~g}$ (TSW3). Means followed by the same uppercase letter in rows and lowercase letter in columns are not significantly different based on the Tukey's test at $5 \%$ of error probability. $\mathrm{CV}=$ coefficient of variation.

Values of electrical conductivity varied significantly ( $\mathrm{p}$ $<0.05$ ) among TSW classes of $P$. rigida and accelerated aging times (Table 3), with interaction between the factors. Seeds with higher weight (TSW2) presented lower electrolyte leakage with or without accelerated aging ( 24 or $48 \mathrm{~h}$ ) in relation to other seed sizes. On the other hand, $P$. rigida seeds with lower weight (TSW3) showed an increase in electrolyte leakage in response to the accelerated aging time. At 0 and $24 \mathrm{~h}$ of aging, a significant difference in electrolyte leakage was observed between seeds with higher weight (TSW2) and the others classes (TSW1 and TSW3), but the increase of aging for $48 \mathrm{~h}$ resulted in a significant difference among means of conductivity of the three weight classes.

There was no significant interaction $(p>0.05)$ between seed weight and accelerated aging for cumulative emergence and emergence velocity index (EVI) (Table 4), however, means of emergence and EVI of $P$. rigida seedlings differed among seed weight classes. 
Tabela 3. Electrical conductivity $\left(\mu \mathrm{S} \mathrm{cm}^{-1} \mathrm{~g}^{-1}\right)$ of Parapiptadenia rigida seeds from three classes with different thousand seed weight (TSW) submitted to three accelerated aging times.

\begin{tabular}{cccc}
\hline \multirow{2}{*}{ Time (h) } & \multicolumn{3}{c}{ TSW } \\
\cline { 2 - 4 } & Class 1 & Class 2 & Class 3 \\
\hline 0 & $148.00 \mathrm{Ab}$ & $93.75 \mathrm{Aa}$ & $140.82 \mathrm{Ab}$ \\
24 & $181.25 \mathrm{Ab}$ & $90.67 \mathrm{Aa}$ & $166.43 \mathrm{ABb}$ \\
48 & $152.32 \mathrm{Ab}$ & $94.20 \mathrm{Aa}$ & $195.78 \mathrm{Bc}$ \\
\hline CV (\%) & & 14.38 & \\
\hline
\end{tabular}

TSW: Class $1=19.23 \mathrm{~g}$ (control); Class 2=25.45 g (TSW2); Class $3=13.58 \mathrm{~g}$ (TSW3). Means followed by the same uppercase letter in rows and lowercase letter in columns are not significantly different based on the Tukey's test at $5 \%$ of error probability. $\mathrm{CV}=$ coefficient of variation.

Table 4. Percentage of emergence and emergence velocity index (EVI) of Parapiptadenia rigida seedlings as affected by three classes with different thousand seed weight (TSW) and three accelerated aging times.

\begin{tabular}{ccc}
\hline & Emergence (\%) & EVI \\
\hline TSW (g) & & \\
\hline Class 1 & $71.16 \mathrm{~b}$ & $23.16 \mathrm{~b}$ \\
Class 2 & $85.50 \mathrm{a}$ & $31.63 \mathrm{a}$ \\
Class 3 & $36.00 \mathrm{c}$ & $12.36 \mathrm{c}$ \\
\hline Time (h) & & \\
\hline 0 & $73.66 \mathrm{a}$ & $25.04 \mathrm{a}$ \\
24 & $55.33 \mathrm{~b}$ & $20.50 \mathrm{~b}$ \\
48 & $63.66 \mathrm{~b}$ & $21.61 \mathrm{ab}$ \\
\hline CV (\%) & 14.13 & 16.99 \\
\hline
\end{tabular}

TSW: Class $1=19.23 \mathrm{~g}$ (control); Class $2=25.45 \mathrm{~g}$ (TSW2); Class $3=$ $13.58 \mathrm{~g}$ (TSW3). Means followed by the same letter are not significantly different based on the Tukey's test at $5 \%$ of error probability. $\mathrm{CV}=$ coefficient of variation.

P. rigida seeds with higher weight (TSW2) germinated faster (Table 5). Regarding the accelerated aging times, only small seeds presented statistical differences and aging for $24 \mathrm{~h}$ resulted in a higher number of days for emergence.

Table 5. Velocity of emergence of Parapiptadenia rigida seedlings from three thousand seed weight (TSW) classes subjected to three accelerated aging times.

\begin{tabular}{cccc}
\hline \multirow{2}{*}{ Time (h) } & \multicolumn{3}{c}{ TSW } \\
\cline { 2 - 4 } & Class 1 & Class 2 & Class 3 \\
\hline 0 & $5.99 \mathrm{ABa}$ & $5.94 \mathrm{Ba}$ & $6.07 \mathrm{Ab}$ \\
24 & $5.99 \mathrm{Ba}$ & $5.91 \mathrm{Ba}$ & $6.24 \mathrm{Aa}$ \\
48 & $6.10 \mathrm{Aa}$ & $5.94 \mathrm{Ba}$ & $6.14 \mathrm{Ab}$ \\
\hline CV $(\%)$ & & 1.23 & \\
\hline
\end{tabular}

TSW: Class $1=19.23 \mathrm{~g}$ (control); Class $2=25.45 \mathrm{~g}$ (TSW2); Class $3=13.58 \mathrm{~g}$ (TSW3). Means followed by the same uppercase letter in rows and lowercase letter in columns are not significantly different based on the Tukey's test at $5 \%$ of error probability. $\mathrm{CV}=$ coefficient of variation.

\section{Discussion}

The findings of the present study evidence the ability of Parapiptadenia rigida seeds with higher weight to germinate faster. It indicates that the amount of reserves (higher weight) of seeds is directly related to their physiological quality. In general, high weight seeds exhibit higher germination capacity when compared to low weight seeds when exposed to low stress conditions (Genna \& Pérez, 2016). For some forest species, it has been shown that germination and vigor of seedlings are related to seed weight (or size) (Du \& Huang, 2008; Owoh et al., 2011; Socolowski et al., 2011 a; Landergott et al., 2012; Kuniyal et al., 2013), but other species show no influence (Khera et al., 2004; Freire et al., 2015).

The main feature of seed aging is the decrease in germination velocity of viable seeds, followed by reduction in seedling length and increase in abnormal seedlings (Marcos Filho et al., 2015). In the present study, we observed that seedlings produced from seeds with higher thousand seed weight (TSW2) showed high mean of shoot length and fresh weight, evidencing that $P$. rigida seedlings produced from seeds with higher TSW are more vigorous.

Seeds with higher TSW under accelerated aging conditions presented higher percentages of germination and lower mortality rate. According to Marcos Filho et al. (2015), decrease in germination has of seeds been associated with initial signs of cellular membrane disorganization. This suggests that seeds with higher weight (TSW) have greater tolerance to adverse conditions that result in accelerate deterioration process.

Seed deterioration is a complex biochemical and physiological process that leads to loss of germination capacity and electrolyte leakage is one associatedfeature that indicates the cellular damage extension (Kaewnaree et al., 2011). Furthermore, a reduction in germination, emergence in the field and vigor of the seedlings are linked to a high electrolyte leakage of the seeds (Mahjabin \& Abidi, 2015). It is evidenced that seeds with lower weight are more sensitive to stress conditions promoted by accelerated aging. Therefore, it is assumed that $P$. rigida seeds with higher TSW keep the vigor under accelerated aging conditions up to 48 $\mathrm{h}$ since they present characteristics that provide higher tolerance, what makes possible to choose of seeds for greater success in germination under stress conditions.

The effect of seed weight in survival and seedling performance may be more pronounced under conditions 
of abiotic stress or limited resources availability (Suárez-Vidal et al., 2017). In our study, we verified a similar trend, in which $P$. rigida seeds with greater weight (TSW) showed a higher tolerance to accelerated aging conditions, since they kept a stable electrical conductivity. On the other hand, small seeds showed increased electrical conductivity with increasing accelerated aging time. Seeds with intermediate TSW also presented variation in electrical conductivity as a response to the accelerated aging time (Table 3 ).

The physiological quality of the seeds may influence directly emergence rate and total emergence (Pádua et al., 2010). Generally, a large seed has greater reserve, which can be used by seedling in the early stages of growth (Baskin \& Baskin, 2014). However, germination and seedling growth of species such as $T$. grandis (Khera et al., 2004) and $S$. parahyba (Freire et al., 2015) were not affected by seed size. In the present study, it was evident that higher means of cumulative emergence and emergence velocity index were associated with the physiological quality afforded by seed weight. Seeds with higher TSW tend to present more physiological resources for faster emergence, which may allow the establishment of seedling stands in nursery conditions with greater uniformity, besides reducing the time of exposure of seeds to biotic and abiotic factors.

Seeds with high weight present higher energy reserves (Baskin \& Baskin, 2014), which can be consumed during accelerated aging through respiration process. Therefore, P. rigida seeds with more reserves (high TSW) showed better germination performance after the accelerated aging process in laboratory and greenhouse conditions, making them more tolerant than seeds with lower weight. Seed size (weight) is an important survival predictor; phenotype and recruitment of seedlings in general have a straight relationship with seed size, being accepted that larger seeds produce seedlings with better performance (Suárez-Vidal et al., 2017).

Tree species seedlings originated from small seeds may present reduced growth and low dry weight, which represents a competitive disadvantage because it diminishes the success in establishment under natural conditions (Khera et al., 2004). Additionally, seed classification based on size/weight is a very useful practice to minimize variation in seedling growth under nursery conditions (Alves et al., 2005; Mishra et al., 2014). We verified that $P$. rigida seeds with higher TSW presented greater vigor relative to the seeds of the original lot (mixed seeds with several weights) and those with lower TSW (TSW1). Thus, we suggest that seed lots of $P$. rigida should be made up of seeds that are classified by TSW.

\section{Conclusions}

Germination and vigor of Parapiptadenia rigida seeds are influenced by the seed weight.

Seeds of $P$. rigida with high weight display a greater tolerance to accelerated aging conditions and grow more vigorous seedlings.

The classification of $P$. rigida seeds based on higher size or weight is a recommended technique for sowing in nursery.

\section{References}

Alves, E. U. et al. Influência do tamanho e da procedência de sementes de Mimosa caesalpiniifolia Benth. sobre a germinação e vigor. Revista Árvore, v. 29, n. 6, p. 877-885, 2005. DOI: 10.1590/ S0100-67622005000600006.

Ambika, S. et al. Review on effect of seed size on seedling vigour and seed yield. Research Journal of Seed Science, v. 7, n. 2, p. 31-38, 2014. DOI: 10.3923/rjss.2014.31.38.

Attri, V. et al. Effect of seed size and pre-sowing treatments on growth parameters and biomass of Sapindus mukorossi (Gaertn) seedlings under nursery condition. Environment and Ecology, v. 33, n. 1, p. 46-49, 2015.

Baskin, C. C. \& Baskin, J. M. Seeds: ecology, biogeography, and evolution of dormancy and germination. Amsterdam: Academic Press, 2014. 1600 p.

Brasil. Ministério da Agricultura e Reforma Agrária. Secretaria de Defesa Agropecuária. Instruções para análise de sementes de espécies florestais. Brasília, DF, 2013. 97 p.

Brasil. Ministério da Agricultura e Reforma Agrária. Secretaria de Defesa Agropecuária. Regras para análise de sementes. Brasília, DF, 2009. 398 p.

Carvalho, N. M. \& Nakagawa, J. Sementes: ciência, tecnologia e produção. 5 ed. Jaboticabal: FUNEP, 2012. 590 p.

Carvalho, P. E. R. Angico-Gurucaia. Colombo: Embrapa Florestas, 2002. 14 p. (Embrapa Florestas. Circular técnica, 58).

Du, Y. \& Huang, Z. Effects of seed mass and emergence time on seedling performance in Castanopsis chinensis. Forest Ecology and Management, v. 255, n. 7, p. 2495-2501, 2008. DOI: 10.1016/j. foreco.2008.01.013.

Edmond, J. B. \& Drapala, W. J. The effects of temperature, sand and soil, and acetone on germination of okra seeds. Proceedings of the American Society Horticultural Science, v. 71, n. 5, p. 428-434, 1958. 
Ferreira, D. F. Sisvar: a computer statistical analysis system. Ciência e Agrotecnologia, v. 35, n. 6, p. 1039-1042, 2011. DOI: 10.1590/ S1413-70542011000600001.

Finch-Savage, W. E. \& Bassel, G. W. Seed vigour and crop establishment: extending performance beyond adaptation. Journal of Experimental Botany, v. 67, n. 3, p. 567-591, 2016. DOI: 10.1093/ jxb/erv490.

Freire, J. M. et al. Intra-and inter-population variation in seed size and dormancy in Schizolobium parahyba (Vell.) Blake in the Atlantic Forest. Ciência Florestal, v. 25, n. 4, p. 897-907, 2015. DOI: $10.5902 / 1980509820592$.

Genna, N. G. \& Pérez, H. E. Mass-based germination dynamics of Rudbeckia mollis (Asteraceae) seeds following thermal and ageing stress. Seed Science Research, v. 26, n. 3, p. 231-244, 2016. DOI: 10.1017/S0960258516000180.

Ghaffaripour, S. et al. The importance of seed reserve on performance and breeding of tamarind seedlings. Scientia Horticulturae, v. 222, p. 145-152, 2017. DOI: 10.1016/j.scienta.2017.04.032.

Gnan, S. et al. The genetic basis of natural variation in seed size and seed number and their trade-off using Arabidopsis thaliana MAGIC lines. Genetics, v. 198, n. 4, p. 1751-1758, 2014. DOI: 10.1534/ genetics.114.170746.

Kaewnaree, P. et al. Effect of accelerated aging process on seed quality and biochemical changes in sweet pepper (Capsicum annuum Linn.) seeds. Biotechnology, v. 10, n. 2, p. 175-182, 2011. DOI: 10.3923/biotech.2011.175.182.

Khera, N. et al. Seed size variability and its influence on germination and seedling growth of five multipurpose tree species. Seed Science and Technology, v. 32, n. 2, p. 319-330, 2004. DOI: 0.15258/ sst.2004.32.2.05.

Krzyzanowski, F. C. et al. (Ed.). Vigor de sementes: conceitos e testes. Londrina: ABRATES, 1999. 218 p.

Kuniyal, C. P. et al. Seed size correlates seedling emergence in Terminalia bellerica. South African Journal of Botany, v. 87, p. 92-94, 2013. DOI: 10.1016/j.sajb.2013.03.016.

Landergott, U. et al. Effects of seed mass on seedling height and competition in European white oaks. Flora, v. 207, n. 10, p. 721-725, 2012. DOI: 10.1016/j.flora.2012.09.001

Li, N. \& Li, Y. Signaling pathways of seed size control in plants. Current Opinion in Plant Biology, v. 33, p. 23-32, 2016. DOI: 10.1016/j.pbi.2016.05.008.

Lorenzi, H. Árvores brasileiras: manual de identificação e cultivo de plantas arbóreas nativas do Brasil. Nova Odessa: Plantarum, 1992. $352 \mathrm{p}$.

Maguire, J. D. Speed of germination-aid in selection and evaluation for seedling emergence and vigor. Crop Science, v. 2, n. 2, p. 176177, 1962. DOI: 10.2135/cropsci1962.0011183X000200020033x.

Mahjabin, S. B. \& Abidi, A. B. Physiological and biochemical changes during seed deterioration: a review. International Journal of Recent Scientific Research, v. 6, n. 4, p. 3416-3422, 2015.
Marcos Filho, J. Fisiologia de sementes de plantas cultivadas. Piracicaba: FEALQ, 2005. 495 p.

Marcos Filho, J. Seed vigor testing: an overview of the past, present and future perspective. Scientia Agricola, v. 72, n. 4, p. 363-374, 2015. DOI: 10.1590/0103-9016-2015-0007.

McDonald Junior, M. B. \& Phaneendranath, B. R. A modified accelerated aging vigor test procedure. Journal of Seed Technology, v. 3, n. 1, p. 27-37, 1978.

Mishra, Y. et al. Effect of seed mass on emergence and seedling development in Pterocarpus marsupium Roxb. Journal of Forestry Research, v. 25, n. 2, p. 415-418, 2014. DOI: 10.1007/s11676-0140469-7.

Mondo, V. H. V. et al. Teste de germinação de sementes de Parapiptadenia rigida (Benth.) Brenan (Fabaceae). Revista Brasileira de Sementes, v. 30, n. 2, p. 177-183, 2008. DOI: 10.1590/ S0101-31222008000200022.

Owoh, P. W. et al. Effects of seed size on germination and early morphological and physiological characteristics of Gmelina arborea, Roxb. African Research Review, v. 5, n. 6, p. 422-433, 2011. DOI: 10.4314/afrrev.v5i6.33.

Padua, G. P. et al. Influência do tamanho da semente na qualidade fisiológica e na produtividade da cultura da soja. Revista Brasileira de Sementes, v. 32, n. 3, p. 9-16, 2010. DOI: 10.1590/S010131222010000300001 .

Piña-Rodrigues, F. C. M. et al. Testes de qualidade. In: Ferreira, A. G. \& Borgheti, F. Germinação: do básico ao aplicado. Porto Alegre: Artmed, 2004. p. 283-297.

Silva, D. C. et al. Evidence of ecotypic differentiation between populations of the tree species Parapiptadenia rigida due to flooding. Genetics and Molecular Research, v. 9, n. 2, p. 797-810, 2010. DOI: $10.4238 /$ vol9-2gmr736.

Socolowski, F. et al. Seed weight of Xylopia aromatica (Annonaceae): quality evaluation from X-ray and seedling emergence. Scientia Agricola, v. 68, n. 6, p. 643-646, 2011a. DOI: 10.1590/S010390162011000600006.

Socolowski, F. Massa das sementes de Tecoma stans L. Juss. ex Kunth (Bignoniaceae): efeitos na emergência e desenvolvimento de suas plântulas no sol e na sombra. Biota Neotropica, v. 11, n. 2, p. 171-178, 2011b. DOI: 10.1590/S1676-06032011000200017.

Suárez-Vidal, E. et al. Is the benefit of larger seed provisioning on seedling performance greater under abiotic stress? Environmental and Experimental Botany, v. 134, p. 45-53, 2017. DOI: 10.1016/j. envexpbot.2016.11.001.

Vieira, R. D. \& Krzyzanowski, F. C. Teste de condutividade elétrica. In: Krzyzanowski, F. C. et al. (Ed.). Vigor de sementes: conceitos e testes. Londrina: ABRATES, 1999. p. 1- 26.

Yang, L. \& Wen, B. Seed quality. In: Thomas, B. et al. Encyclopedia of applied plant sciences. 2nd ed. Amsterdam: Elsevier, 2017. p. 553-563. 